\title{
The BRICS in the Contemporary Global Order: Objectives, Capabilities, and Limitations
}

\author{
Alberto Hoyos Varela', Rafael Gustavo Miranda Delgado²*) \\ ${ }^{1}$ The Basic Cycle of General Studies, Universidad Simón Bolívar, Sartenejas, Caracas, \\ Miranda, Venezuela. \\ ${ }^{2}$ Research Group on Development and Democracy Studies, Institute of Economic and Social Research \\ Universidad de Los Andes, Merida 5101, Mérida, Venezuela.
}

Received: 1 June 2019; Revised: 11 July 2019; Accepted: 24 July 2019

\begin{abstract}
For the first time in the history of mankind several powers emerge simultaneously in different latitudes and can interact intensively. The Contemporary Global Order has presented significant changes among which highlight the absolute and relative decline of American power, and the emergence of new actors who have greater agency power in their international relations. One of these actors is the so-called BRICS that brings together Brazil, Russia, India, China and South Africa. For this reason the aim of this investigation is to analyzing the effective and potential power of the BRICS in the Contemporary Global Order. The methodology is it is situated inside the analytical eclecticism which is characterized by explaining a certain phenomenon without using a block of explanations sustained in a single tradition, but it takes and re-means the elements that it considers most pertinent for the case study. The article states that the BRICS do not claim or have the capacity to become hegemons. The objectives and capabilities of the BRICS have been especially notable in terms of international political economy, especially in the financial architecture, where China has its greatest power. The BRICS can promote an alternative to the existing game rules in the international system and promote a more plural world. They have the capacity to reform and build international economic institutions that allow a fairer distribution of material resources. They can curb unilateral global power interventions in regional affairs, framing interventions for humanitarian causes within multilateralism and the Responsibility to Protect. In terms of democracy and human rights, they will not make any contribution since their main actors, such as China and Russia, are examples of disrespect for these values.
\end{abstract}

Keywords: BRICS; Contemporary Global Order; International political economy; International institutions; Global governance

How to Cite: Varela, A. H., \& Delgado, R. G. M. (2019). The BRICS in the Contemporary Global Order: Objectives, Capabilities, and Limitations. Otoritas : Jurnal Ilmu Pemerintahan, 9(2), 89-106.

Permalink/DOI: https://doi.org/10.26618/ojip.v9i2.2106

${ }^{*}$ Corresponding Author.

E-Mail : rafaelgustavomd@hotmail.com

Copyright (C) 2019, Otoritas : Jurnal Ilmu Pemerintahan, ISSN: 2088-3706 (Print), ISSN: 2502-9320 (Online) 
Available Online at https://journal.unismuh.ac.id/index.php/otoritas

Otoritas : Jurnal Ilmu Pemerintahan, 9 (2), October 2019, 90

\section{INTRODUCTION}

For the first time in the history of mankind several powers emerge simultaneously in different latitudes and can interact intensively. The emergence of the Global South is the most significant phenomenon of the contemporary Global Order, reconfigures the dynamics of power, international institutions and international political economy. The Contemporary Global Order has presented significant changes among which highlight the absolute and relative decline of American power, and the emergence of new actors who have greater agency power in their international relations. One of these actors is the so-called BRICS that brings together Brazil, Russia, India, China and South Africa. These countries share an increasingly large economic and commercial weight worldwide, a significant demographic weight and a large territorial area with natural resources.

For this reason the aim of this investigation is to analyzing the effective and potential power of the BRICS in the Contemporary Global Order. The hypothesis of the investigation is that the BRICS do not claim or have the capacity to become hegemons, but their objectives and capabilities are especially notable in terms of international political economy, where have a strategy in two spaces, seeking to reform the institutions of the international economic system and creating new alternative institutions. The methodology is it is situated inside the analytical eclecticism which is characterized by explaining a certain phenomenon without using a block of explanations sustained in a single tradition, but it takes and re-means the elements that it considers most pertinent for the case study.

The research is presented in three sections, BRICS Agenda has the purpose of analyzing the objectives of the BRICS through their joint declarations and the materialization or not of the proposed ob- jectives; In BRICS countries: material and politic elements, the aim is to compare the agency capabilities of each of the countries that make up the BRICS, and finally the Role of the BRICS in the Contemporary Global Order analyzes the influence of the BRICS over the Contemporary Global Order.

\section{RESEARCH METHODS}

The methodology is it is situated inside the analytical eclecticism which is characterized by explaining a certain phenomenon without using a block of explanations sustained in a single tradition, but it takes and re-means the elements that it considers most pertinent for the case study. In this research, it is taken from the realist tradition, in its neorealist variables (Waltz, 1979) and the transition of power (Kugler \& Organski, 1989), the distribution and inequality of material capacities, the policies of balance and counter- balance, and status in the international hierarchy. From the liberal tradition (Keohane \& Nye, 2012) the analysis of international institutions is taken, especially that of the International Political Economy. Constructivism (Wendt, 1992) rescues the importance of socially constructed interests and the world view generated by the context and the interaction of the actors. And, with greater emphasis, the critical tradition of the Global South (Acharya, 2018; Acharya, 2014) that not only complies with a description of the global order, but also proposes a new one, more just and plural governance from the Global South.

Additionally, The heterogeneity within the BRICS group is noticed, so comparative analysis is used. The comparison allows determining similarities and differences between countries, allowing a broader understanding of the variables subject to study, relating them to a set of categories of a general theory. The comparison with its inductive tracking method is of the event type - disaggregat- 
ed and systemic structure, which constitutes the causal interpretation.

Finally, the analytic instrument used are mixed, including discourse analysis of joint official statements, descriptive statistics and analysis of conjuncture, all in dialogue with a theoretical framework that problematizes fundamental categories such as emerging power and regional power.

\section{RESULTS AND DISCUSSION BRICS Agenda}

The immediate background of the BRICS can be found in the Eurasian strategic triangle RIC (Russia, India and China) that since the 1990s presented proposals for the development of Asia and for issues of security and terrorism, and in the IBSA forums (India, Brazil, South Africa) of the 2000s that focused on making diagnoses and criticisms of international financial organizations. In 2005 Brazil, Russia, India and China attended the Group of Eight summit (G-8) where there were certain approaches, then in 2006 the first formal meeting of the BRIC countries (without South Africa) took place in the United Nations System (UN) where the Ministers of Foreign Affairs met in the framework of the General Assembly. Subsequently, consultations began among the member countries of the BRICs, meetings of foreign ministers at the UN and meetings of presidents of the Central Banks in the framework of the summit of the Group of Twenty (G-20). Finally, at the meeting of June 16, 2009 at the summit of Yekaterinbourg Russia, the identity and objectives of the group were constituted (Stunkel, 2015; Luna, 2011).

The financial crisis of 2008 served as a privileged scenario for the promotion of the BRICS and printed its profile with emphasis on the international political economy. The financial crisis not only questioned the material capacity of the central countries but also questioned the effectiveness of the liberal economic institu- tions and their model of doing politics.

The financial crisis of 2008 was a consequence of the reduction of profit rates in the international economy. In much of the Western world, especially in the United States, the rate of profit of nonfinancial companies fell significantly in the periods from 1950 to 1973 and from 2000 to 2006, thus initiating a significant shift of capital in the direction of financial activity, All this in a context of rapid deregulation of financial systems and the almost unrestricted liberalization of international capital movements. Thus, the growth of the world economy is largely linked to speculative bubbles (Brenner, 2009). This evidenced the need to expand the participation of emerging economies in the world economy and its institutions (Stuenkel, 2015).

The countries of the Global South in general and the BRICS in particular managed to face the economic crisis of 2008 because their development models followed different paths to the neoliberalism promoted by the international economic institutions of the Bretton Woods, the International Monetary Fund and the World Bank. These countries in general have been characterized by State Capitalism, based on a strong state intervention to promote productive development policies and structural change based on exports, in addition to providing conditions to attract foreign direct investment (Chang, 2009; Kiely, 2015).

In this context of 2008, the G-20 summit took place where the BRICs gave a joint statement highlighting the importance of the participation of these countries in that summit to deal with the financial crisis, and the interest of these countries to achieve reform international institutions to reflect the new international scenario, including its greater gravitation.

After this joint declaration, the first formal meeting was held as a group at the aforementioned summit of Yekaterin- 
Available Online at https://journal.unismuh.ac.id/index.php/otoritas

Otoritas : Jurnal Ilmu Pemerintahan, 9 (2), October 2019, 92

Table 1. BRICS Summit

Source: Processed by the authors (2019)

\begin{tabular}{|c|c|c|c|}
\hline Summit & Place & Date & Goals \\
\hline First Summit & $\begin{array}{l}\text { Yekaterinbourg } \\
\text { (Rusia) }\end{array}$ & June 16, 2009 & $\begin{array}{l}\text { Strengthen the identity of the group and the } \\
\text { questioning of the international economic or- } \\
\text { der }\end{array}$ \\
\hline Second summit & Brasilia (Brasil) & April 15-16, 2010 & $\begin{array}{l}\text { Questioning the international monetary sys- } \\
\text { tem; and cooperation agreements in science } \\
\text { and education. }\end{array}$ \\
\hline Third Summit & Sanya (China) & April 14, 2011 & $\begin{array}{l}\text { Criticism of the International Monetary Sys- } \\
\text { tem }\end{array}$ \\
\hline Fourth Summit & Nueva Delhi (India) & March 29, 2012 & $\begin{array}{l}\text { Proposal for the creation of a new BRICS de- } \\
\text { velopment bank }\end{array}$ \\
\hline Fifth Summit & Durban (Sudáfrica) & March 26-27, 2013 & $\begin{array}{l}\text { The objectives of the new Development Bank, } \\
\text { the initial capital contribution that would be in } \\
\text { the USD } 100 \text { billion and cooperation with Afri- } \\
\text { can countries. }\end{array}$ \\
\hline Sixth Summit & Fortaleza (Brasil) & June 14-16, 2014 & $\begin{array}{l}\text { Constitution of the Development Bank and } \\
\text { contingency reserve agreements of approxi- } \\
\text { mately 10,000 million dollars. BRICS-UNASUR } \\
\text { Summit. }\end{array}$ \\
\hline Seventh Summit & Ufá (Rusia) & July 8 - 9, 2015 & $\begin{array}{l}\text { Meeting with the countries of the Eurasian } \\
\text { Economic Community. The first meeting of the } \\
\text { governing board of the Development Bank of } \\
\text { the BRICS. The creation of an Asian Infrastruc- } \\
\text { ture Investment Bank headed by China is an- } \\
\text { nounced. }\end{array}$ \\
\hline
\end{tabular}

Eighth Summit Benaulim (India) October 15 - 16, 2016 The creation of a risk rating agency of the group was announced, in addition to an emergency reserve agreement that serves as an alternative proposal to the IMF and WB. European countries are asked to give up two of their positions on the IMF board of governors to countries with emerging economies.

Ninth Summit Xiamen (China) September 3-4,2017 The strengthening of the New Development Bank of the BRICS was discussed. Meeting with the heads of state of Mexico, Egypt, Thailand, Tajikistan and Guinea. The crisis in the Korean Peninsula, promote investment agreements in infrastructure and customs, It is mentioned that the international financial institutions must be reformed to improve global governance.

Tenth Summit Johannesburgo July $26-27,2018$ Meeting with African heads of State, in addi(Sudáfrica) tion to the leaders of Argentina, Indonesia, Egypt, Jamaica and Turkey. It was discussed that group countries should increase trade between them. The anti-terrorist struggle was taken into account in the debates and meetings. The rules prevailing in the current trade were criticized because they generate harmful effects in the African countries, besides considering that the war of tariffs affected the global trade flows. 
bourg Russia 2009. This meeting was characterized by denunciations of institutions from Bretton Woods, the use of the dollar as a reserve currency and world trade, and calls for these institutions to be reformed and adapted to the changes that are occurring in the international system. As we will see, these issues of international political economy have been central to all the summits held by the BRICS.

The first two points of the joint declaration show the purpose of changing the rules of the game on which the international economic system is based, which favor the United States and its main partners. Additionally, it is a way in which the BRICS are aware of their role as emerging economies and that the recovery from the crisis also depends on them. One aspect that stood out was the questioning of the use of the dollar as a reserve of value and medium of change in the world economy, which strengthens the disparity of the current economic agency. Other element found in the 2009 declaration is that multilateral trade should stabilize so that progress can be made in the Doha Round negotiations that are suspended. Issues such as climate change and sustainable development were also discussed.

However, the criticisms were focused on the fact that financial crises must be confronted in a better way and avoid the devaluation of the dollar. So far they have not sought an attack against the dollar to generate a crisis against that currency. For example, although the BRICS proposed as co-operation within the group a line of credit in their national currencies to promote development and trade, they did not change from dollars to other currencies their reserves that represent around a third of the world reserves (Struenkel, 2015).

In the fifth part of the joint statement, the importance of coordination and collaboration in the energy issue is exposed to reduce the levels of uncertainty and volatility of the latter. In point six, UN reform was requested so that it could be more efficient when facing global problems. Point seven pointed to the commitment in science and education. Followed in table 1 are the summits held and their main objectives.

From the summits, it can be highlighted that in the third, South Africa became a member of the club, being the only African country considered as an emerging power (Mandrup \& Smith, 2015). At the fourth summit, the intention to create a new development bank was declared, although it did not materialize immediately, it was registered as part of the agenda for the next meeting. The fifth summit based in Durban South Africa focused on the cooperation relations of Africa and the BRICS, and the sixth summit held in Brazil had as guests Argentina and there was a meeting with the Union of South American Nations (UNASUR).

The last two mentioned summits opened several meetings between the BRICS with different regions, within the framework of South-South cooperation. As highlighted by Gu, Carey, Shankland, \& Chenoy (2016) the BRICS have criticized the international cooperation proposals that have been implemented so far, and have applied new practices such as technical and financial assistance without demanding reforms or implementing economic policies as a counterpart, distinguishing itself from the traditional form of Bretton Woods financial organizations.

China and Russia who are the main lenders of the BRICS are especially critical of conditional aid and have provided assistance without economic policy constraints, let alone take into account human rights or democracy; however macroeconomic and social instability in countries as Venezuela and Sri Lanka have made the corresponding payments impossible. In another aspect, the promotion of the model of State capitalism with the Chinese characteristics is another way to promote cooperation, some African coun- 
tries such as Ethiopia have sought advice in this regard (Gu, Carey, Shankland, \& Chenoy (2016); Kiely, 2015).

At these summits, the invited nonmember countries denounce the inequities of the current international economic system; they also seek to attract investments or trade agreements with the members of the BRICS and create new cooperation mechanisms for development (Struenkel, 2015). The invitation of nonmembers of the BRICS seeks to promote critical positions towards international economic institutions. Additionally, they serve to promote cooperation and trade agreements between some countries and regions.

The new BRICS Development Bank (NBD BRICS), the agreements to materialize it and the contribution of capital with a fund in Yuan were also created at the sixth summit. The NBD BRICS is an ideal instrument for development offerings for member countries as well as for nonmembers, and thus attract other emerging countries and other regional integration groups such as the Eurasian Economic Community that was invited to the summit held in Russia and the African Union that was invited to the summit held in South Africa. The BRICS NBD is one of the main bets of the BRICS and particularly of China, especially after China is not satisfied with the increase of its share of votes in the International Monetary Fund.

For China, the creation of the NBD BRICS is a way to avoid the obstacles it may encounter in order to move up in the decision making of the international financial system. China has other multilateral financial initiatives such as the Asian Investment and Infrastructure Bank, the Silk Road and the Road and Belt Initiative. All these initiatives seek to project the Asian giant as a leader in financial globalization, in addition to having a presence in areas that it considers of vital importance to achieve its goal of global power.

Finally, while the focus and continui- ty of the BRICS agenda has been centered on the international political economy and its institutions, political institutions such as the UN Security Council have also been questioned, asking for the enlargement of its members permanent, which is of special interest for Brazil, India and South Africa as non-permanent countries at present (Coning, 2015). At the UN, they have also maintained a critical position in the face of unilateral interventions from the countries of the North, as in the case of Libya, and have maintained relations with different countries regardless of their internal political regime, although they have not agreed on other issues such as the climate change (Odgaard \& Zhadaojiong, 2015).

All these initiatives and summits serve to defuse the internal conflicts of the group and to generate the image of cohesion of emerging economies and the Global South in general, which seek to give international institutions a greater plurality.

So far, although the BRICS group has made some progress, they do not make up a forum or a trade integration pact, and they do not have significant binding agreements and their progress as exemplified by the creation of a customs agreement is timid. Its objectives have been other, and the fulfillment of them depends on the material and political capacities of each one of the countries.

\section{BRICS Countries: Material and Policy Elements}

The conditions of each country that make up the BRICS are different, not all have the same weightings within the group, nor within the regional and global order. Therefore it is necessary to analyze its material and policy elements individually.

China in the BRICS group plays an increasing leadership role with its credentials of global power due to its economic and financial conditions and the size of its 
Available Online at https://journal.unismuh.ac.id/index.php/otoritas

Otoritas : Jurnal Ilmu Pemerintahan, 9 (2), October 2019, 95

market. The other countries seek to increase their weight, Brazil, India and South Africa are regional powers, and Russia seeks to project itself as powers of global importance but needs multilateralism to be able to obtain results in its actions within the international system.

China is an emerging power with global character. China is the most important country in the BRICS, in fact its GDP is three times more than that of India and Russia, it is the most populated country in the world, and it is one of the largest countries in the world with an area of $9,596,961 \mathrm{~km} 2$. It is also a nuclear power, has the army in the largest soldiers in the world and has an ambitious investment policy in armaments and military technology, with special emphasis on the presence in the China Sea. China along with India tilted the world towards Asia (LuftKorin, 2009).

China is the country of the BRICS that has greater material capacity to promote large projects; its geopolitical interests are expressed in its foreign policy first regionally in Central Asia and South- east Asia, and then Africa and Latin America. For example, more than 3,000 Chinese companies operate in Africa and range from large state-owned companies to private small and medium enterprises (Gu, Carey, Shankland, \& Chenoy, 2016). They also highlight cooperation policies and investment in development infrastructure such as hydroelectric dams, railroads and airports, among others in Central Asia and Africa (Gu, Carey, Shankland, \& Chenoy, 2016). Table 2 shows the summary of China's material elements.

China is a nuclear power, it has become the manufacturing center of the world, it is the main holder of debt of the United States, it has an active policy to obtain raw materials and it has become a financier in projects of the countries of Africa and South America. (Luna, 2011). Even authors like Ikenberry (2008) warn of a transfer of US hegemony to China and suggest that the United States cooperate with China in order to preserve its preeminence on the international stage.

The US-Chinese rivalry has been diplomatic and commercial and no short-

Table 2. Material elements of China

Source: World Bank (2019)

\begin{tabular}{lcccccc}
\hline Years & $\begin{array}{c}\text { GDP } \\
\text { (US \$ at con- } \\
\text { stant 2010 } \\
\text { prices) }\end{array}$ & Population & $\begin{array}{c}\text { Foreign direct } \\
\text { investment }\end{array}$ & $\begin{array}{c}\text { Exports of } \\
\text { goods and } \\
\text { services } \\
\text { (\% of GDP) }\end{array}$ & $\begin{array}{c}\text { Imports of } \\
\text { goods and } \\
\text { services } \\
\text { (\% of GDP) }\end{array}$ & $\begin{array}{c}\text { Commercial } \\
\text { Opening }\end{array}$ \\
\hline 2008 & $5.04 \mathrm{E}+12$ & 1324655000 & $1.72 \mathrm{E}+11$ & 32.51957332 & 24.933299 & $1.14 \mathrm{E}-11$ \\
2009 & $5.51 \mathrm{E}+12$ & 1331260000 & $1.72 \mathrm{E}+11$ & 24.45665122 & 20.148776 & $8.09 \mathrm{E}-12$ \\
2010 & $6.10 \mathrm{E}+12$ & 1337705000 & $1.72 \mathrm{E}+11$ & 26.26741407 & 22.621885 & $8.01 \mathrm{E}-12$ \\
2011 & $6.68 \mathrm{E}+12$ & 1344130000 & $1.72 \mathrm{E}+11$ & 26.49432272 & 24.105509 & $7.57 \mathrm{E}-12$ \\
2012 & $7.21 \mathrm{E}+12$ & 1350695000 & $1.72 \mathrm{E}+11$ & 25.40819583 & 22.699663 & $6.67 \mathrm{E}-12$ \\
2013 & $7.77 \mathrm{E}+12$ & 1357380000 & $1.72 \mathrm{E}+11$ & 24.50498149 & 22.060253 & $6.00 \mathrm{E}-12$ \\
2014 & $8.33 \mathrm{E}+12$ & 1364270000 & $1.72 \mathrm{E}+11$ & 23.49505827 & 21.381502 & $5.39 \mathrm{E}-12$ \\
2015 & $8.91 \mathrm{E}+12$ & 1371220000 & $1.72 \mathrm{E}+11$ & 21.34807161 & 18.104994 & $4.43 \mathrm{E}-12$ \\
2016 & $9.51 \mathrm{E}+12$ & 1378665000 & $1.72 \mathrm{E}+11$ & 19.65837757 & 17.375439 & $3.90 \mathrm{E}-12$ \\
2017 & $1.02 \mathrm{E}+13$ & 1386395000 & $1.72 \mathrm{E}+11$ & 19.7573801 & 18.046019 & $3.72 \mathrm{E}-12$ \\
\hline
\end{tabular}


Available Online at https://journal.unismuh.ac.id/index.php/otoritas

Otoritas : Jurnal Ilmu Pemerintahan, 9 (2), October 2019, 96

term changes are foreseen. However, China increasingly has a greater military presence in the South China Sea and announces increasing investment in its military sector, especially in the Naval. This can lead to friction with the countries of Southeast Asia, including India, but also Vietnam, Indonesia and the Philippines who are allies of the United States. Another scenario of possible conflict is that generated by the Silk Road initiative due to the natural and historical zone of Russian influence in Central Asia and by the Muslim populations of the countries of Central Asia.

The United States has also denounced that China artificially devalues the Yuan as a practice of unfair competition, does not respect intellectual property rights, and foreign companies cannot operate openly in their territory since they must associate with locals to operate.

However, China maintains a characteristic of coexistence in its foreign policy. This is based on the promotion of order in international relations, in separating the political and economic aspects, and in seeking consensus for intervention in domestic affairs of other countries. Within its foreign policy, it has also intensified cooperation with those countries that maintain opposing or alternative positions to the West. It has also avoided the use of force for the management of conflicts and has peacefully channeled territorial claims (Odgaard \& Daojiong, 2015).

It should also be noted that China still has significant challenges such as reducing poverty especially in rural areas and inequality, pollution problems, and objectives in which it does not show improvements or intensions to improve such as democracy or human rights. Additionally, the Chinese economic growth of the last thirty years has been based on the export of manufactures based on cheap labor, structural change to more complex production sectors is still pending.

Russia, on the other hand, is the largest country in the world with $17,125,246 \mathrm{~km}^{2}$ of surface area; it has one of the largest oil and gas reserves in the world, which are its main sources of tax and foreign exchange earnings. Its geopolitical position is very important since it is

Table 3. Material elements of Russia

Source: World Bank (2019)

\begin{tabular}{lcccccc}
\hline Years & $\begin{array}{c}\text { GDP } \\
\text { (US \$ at con- } \\
\text { stant 2010 } \\
\text { prices) }\end{array}$ & Population & $\begin{array}{c}\text { Foreign direct } \\
\text { investment }\end{array}$ & $\begin{array}{c}\text { Exports of } \\
\text { goods and } \\
\text { services } \\
\text { (\% of GDP) }\end{array}$ & $\begin{array}{c}\text { Imports of } \\
\text { goods and } \\
\text { services } \\
\text { (\% of GDP) }\end{array}$ & $\begin{array}{c}\text { Commercial } \\
\text { Opening }\end{array}$ \\
\hline 2008 & $1.58 \mathrm{E}+12$ & 142742350 & $74,782,910,000$ & 31.30959764 & 22.072932 & $3.37 \mathrm{E}-11$ \\
2009 & $1.46 \mathrm{E}+12$ & 142785342 & $36,583,100,000$ & 27.93811458 & 20.4969696 & $3.32 \mathrm{E}-11$ \\
2010 & $1.52 \mathrm{E}+12$ & 142849449 & $43,167,780,000$ & 29.21558677 & 21.1399635 & $3.30 \mathrm{E}-11$ \\
2011 & $1.61 \mathrm{E}+12$ & 142960868 & $55,083,630,000$ & 27.9769231 & 19.9241769 & $2.98 \mathrm{E}-11$ \\
2012 & $1.66 \mathrm{E}+12$ & 143201676 & 50587560000 & 26.88344496 & 20.2261071 & $2.83 \mathrm{E}-11$ \\
2013 & $1.69 \mathrm{E}+12$ & 143506911 & 69218890000 & 25.79296505 & 20.4003902 & $2.73 \mathrm{E}-11$ \\
2014 & $1.71 \mathrm{E}+12$ & 143819666 & 22031320000 & 27.05302069 & 20.6459224 & $2.80 \mathrm{E}-11$ \\
2015 & $1.66 \mathrm{E}+12$ & 144096870 & 6852970000 & 28.60643166 & 20.5707851 & $2.97 \mathrm{E}-11$ \\
2016 & $1.65 \mathrm{E}+12$ & 144342396 & 32538900000 & 25.69897693 & 20.526401 & $2.79 \mathrm{E}-11$ \\
2017 & $1.68 \mathrm{E}+12$ & 144495044 & 28683950000 & 26.03958651 & 20.6884879 & $2.78 \mathrm{E}-11$ \\
\hline
\end{tabular}


located in Asia and Europe, it borders several countries of Central Asia and some that were part of the former Soviet Union. It is also a nuclear power. Table 3 shows its material indicators.

The increase in fiscal revenues derived from the increase in the price of energy resources was an important tool to strengthen the state authority and the power of Putin, and face internal deterioration with the fall of the USSR and the Boris Yeltsin government, and implement a stronger and tougher foreign policy against the West and the expansion of the North Atlantic Treaty Organization (NATO).

Russia seeks to consolidate itself as a secure energy supplier for China but it presents geopolitical differences with this country due to its respective borders. In the same way there are tensions with the West, for what it considers its zone of influence in the westerly, such as the cases of Ukraine, Georgia and their support for the government of Bashar Al-Assad in Syria. This has led him to be excluded from the G-8, especially by the annexation of the Crimean peninsula in 2014. He even raised his G-20 exclusion but it did not happen at all. That is why the Eurasian country has given importance to the BRICS to avoid international isolation Another Russian interest to participate in the BRICS can be seen in obtaining financing for infrastructure in rural areas and in their areas closer to Asia. In addition to proposing itself as a supplier of energy sources for two major Asian markets, China and India, and thus minimize the impact of possible EU sanctions on their exports.

Like China, Russia raises the possibility of maintaining relations with different political and economic regimes in peaceful coexistence, and denounces foreign interventions in the Middle East and Africa, as in the case of Syria (Fleming \& Sergunin, 2015). It also declares the importance of the self-determination of na- tions and the importance of freedom (Coning, Mandrup \& Odgaard, 2015). However, this contrasts with his policies of interference with the former Soviet space of independent republics in Asia, such as the use of military force in Georgia, the military invasion of the Crimean peninsula or his active participation in Syria.

Although its political and social model is not so attractive for its dissemination in the world beyond those who have declared themselves authoritarian and some of the former Soviet countries, forms of cooperation have been implemented to promote the Russian cultural and educational sectors.

It should be noted that Russia presents great challenges for its economic performance; its growth is highly dependent on the export of gas and oil to Europe. Its industrial sector, with the exception of the arms industry, is underdeveloped and in many cases in dismantling, which has been happening since the Soviet Union. Poverty also continues to be widespread, especially in its rural areas.

India closes the Eurasian triangle of the BRICS. India is the second most populated country in the world, only behind China, and it is expected that in a few years it will be the most populated country in the world and with a young population. Unlike China and Russia, India is a parliamentary and democratic country. It is one of the countries that have the greatest diversity in the ethnic-religious, cultural and linguistic in the world. Economic growth in recent years has been driven by the service sector, the software industry and electronics. Additionally, during the administration of Prime Minister Narendra Modi important commitments have been made in education, at a basic level and to increase the training of qualified personnel in high technology management, as a way to compete in the world economy. Table 4 summarizes its material capabilities. 
Available Online at https://journal.unismuh.ac.id/index.php/otoritas

Otoritas : Jurnal Ilmu Pemerintahan, 9 (2), October 2019, 98

Indian foreign policy seeks to bring its Southeast Asian neighbors closer. India has significant tensions with China over territorial conflicts and distrust generated by Chinese military activity in the China Sea and the Indian Ocean. India also has a territorial conflict with Pakistan over the Kashmir region, which is especially dangerous since both countries have nuclear power. Of his presence in Africa, his trade stands out, which in 2015 was 72,000 million dollars, his position in forums such as the UN on respect for sovereignty and non -interference in internal affairs, and his interest in obtaining natural resources (Gu, Carey, Shankland, \& Chenoy, 2016).

The foreign policy of India coincides with the Chinese and the Russian in maintaining relations with different countries regardless of the type of internal regime, and does not consider that democracy should be promoted as a political regime in the world. But it differs from these countries because it maintains close ties of cooperation with the United States to increase its security capabilities, it even contributes to the maintenance of the rules of the international liberal order and its institutions while seeking to have a greater participation in them (Gupta \& Chatterjee , 2015).

Among the main challenges facing India, poverty stands out. The World Bank (2013) notes that $42 \%$ of Indians live below the poverty line. Population growth can become an additional challenge for poverty reduction. Finally there are numerous clashes between the populations of the Muslim and Hindu religions.

Brazil is the only American partner that is within the BRICS. It is the country in Latin America with the largest population and the largest South American country with 8.5 million $\mathrm{km} 2$ of surface area and with enormous wealth in natural resources. It is a democratic country. It also has an important economic weight throughout Latin America. Followed in Table 5 are the material indicators of Brazil.

In recent years, Brazilian foreign policy has focused on strengthening regional institutions in South America such as the South American Common Market (MERCOSUR) and the Union of South American Nations (UNASUR). It uses the

Table 4. Material elements of India

Source: World Bank (2019)

\begin{tabular}{lcccccc}
\hline Years & $\begin{array}{c}\text { GDP } \\
\text { (US \$ at con- } \\
\text { stant 2010 } \\
\text { prices) }\end{array}$ & Population & $\begin{array}{c}\text { Foreign direct } \\
\text { investment }\end{array}$ & $\begin{array}{c}\text { Exports of } \\
\text { goods and } \\
\text { services } \\
\text { (\% of GDP) }\end{array}$ & $\begin{array}{c}\text { Imports of } \\
\text { goods and } \\
\text { services } \\
\text { (\% of GDP) }\end{array}$ & $\begin{array}{c}\text { Commercial } \\
\text { Opening }\end{array}$ \\
\hline 2008 & $1.39 \mathrm{E}+12$ & 1197146906 & $4.34 \mathrm{E}+10$ & 24.26743306 & 29.4959396 & $3.88 \mathrm{E}-11$ \\
2009 & $1.50 \mathrm{E}+12$ & 1214270132 & $3.56 \mathrm{E}+10$ & 20.61556009 & 26.161466 & $3.11 \mathrm{E}-11$ \\
2010 & $1.66 \mathrm{E}+12$ & 1230980691 & $2.74 \mathrm{E}+10$ & 22.5904459 & 27.0984454 & $3.00 \mathrm{E}-11$ \\
2011 & $1.77 \mathrm{E}+12$ & 1247236029 & $3.65 \mathrm{E}+10$ & 24.54041132 & 31.0834687 & $3.15 \mathrm{E}-11$ \\
2012 & $1.86 \mathrm{E}+12$ & 1263065852 & $2.40 \mathrm{E}+10$ & 24.53443066 & 31.2592911 & $2.99 \mathrm{E}-11$ \\
2013 & $1.98 \mathrm{E}+12$ & 1278562207 & $2.82 \mathrm{E}+10$ & 25.4308613 & 28.4132707 & $2.72 \mathrm{E}-11$ \\
2014 & $2.13 \mathrm{E}+12$ & 1293859294 & $3.46 \mathrm{E}+10$ & 22.96796301 & 25.9542227 & $2.30 \mathrm{E}-11$ \\
2015 & $2.30 \mathrm{E}+12$ & 1309053980 & $4.40 \mathrm{E}+10$ & 19.82442628 & 22.1222536 & $1.82 \mathrm{E}-11$ \\
2016 & $2.47 \mathrm{E}+12$ & 1324171354 & $4.45 \mathrm{E}+10$ & 19.31492239 & 21.0342569 & $1.64 \mathrm{E}-11$ \\
2017 & $2.63 \mathrm{E}+12$ & 1339180127 & $4.00 \mathrm{E}+10$ & 18.86741471 & 21.7746593 & $1.55 \mathrm{E}-11$ \\
\hline
\end{tabular}


Available Online at https://journal.unismuh.ac.id/index.php/otoritas

Otoritas : Jurnal Ilmu Pemerintahan, 9 (2), October 2019, 99

National Development Bank (BNDES) as a way to finance infrastructure projects in Latin America and Africa. He has sought to have his companies present in Latin America and in Africa, especially in the area of infrastructure construction. It has created cooperation mechanisms with its neighbors in the hemisphere and with the Portuguese-speaking countries of Africa, especially with Angola, Cape Verde and Mozambique (Gu, Carey, Shankland, \& Chenoy, 2016). Brazil has traditionally seen itself as a country that has served as a mediator in the dynamics with the countries of the region (Grotius, 2011). The rapprochement with China was promoted as an opportunity to export raw materials, but causes concern that its industrial sector may be disadvantaged with Asian manufactures. (Castro, 2017).

Finally, since the 2000s, Brazilian activism in multilateral organizations has become a key position in its foreign policy and its new approach towards its regional neighbors. This activism has been based on the idea of the Brazilian identity as a continental country, with special emphasis on regional integration as a new form of international insertion, and on the objective of transforming the country into a global trader in the medium term and turning it into a long-term global player. This strategy of autonomy through integration was proposed during the administration of Fernando Collor de Mello and deepened by Luis Ignacio "Lula" Da Silva (Deciancio, 2013).

Like all the BRICS countries, Brazil faces important challenges in terms of poverty and inequality. Its economic growth is highly dependent on the export of primary products and is restricted by the volatility of the markets. Brazil is the country of the BRICS that invests least in innovation and technology.

Finally, South Africa is the only African country that is a member of this group. It has an area of $1,219,912 \mathrm{~km} 2$; it is located in the southernmost part of the
African continent, bounded in the north by Namibia, Botswana, Zimbabwe and Mozambique, as well as Lesotho and Swaziland. It has one of the highest GDP in Africa, is a large producer and exporter of minerals and raw materials. Since the end of Apartheid in 1993 and the election of Nelson Mandela democracy was established. Table 6 shows the main material elements.

The fundamental interest of South Africa's foreign policy is to be an African countries intermediary in the international forums, as well as to have a commercial and diplomatic presence with its southern neighbors. The African country has participated as the voice of Africa in multilateral organizations since the fall of Apartheid (Stuenkel, 2015). Participation in peace missions and as a mediator in regional conflicts in the region has been fundamental. South Africa's participation in the BRICS group gives it economic benefits through increasing bilateral trade (Mandrup \& Smith, 2015). He has been constantly working to attract Chinese investment in infrastructure.

South Africa's challenge is to reduce social inequality and the poverty of the majority of the black population. It is one of the countries with the highest incidence of AIDS in its population, 1 in 5 people are infected with this disease, $17.9 \%$ of adults are in these conditions, being one of the highest in the world (UNICEF, 2012) . It has one of the highest unemployment rates in the world, which stood at $26.4 \%$ in 2014 for the total population and $48 \%$ for those under 25 years of age (Datosmacro, 2015).

Thus, when looking at the economic performance of the BRICS countries, it can be found that they have an increasing weight in the world economy and trade. However, despite this greater gravitation they maintain important internal challenges, with problems such as poverty, inequality, low diversification and complexity of their economic structures. 
India, Brazil, South Africa and especially Russia, can be considered regional powers because of their relative advantageous position with respect to their neighbors, but the great actor of the BRICS is China. China stands out within the group and globally in terms of economic growth, territory and population, but its geopolitical superiority is based especially on its financial capacity. Its projection as a world power depends in large part on the strengthening of the BRICS and its leadership position internally.

Their positions of coexistence allow them to reach agreements despite their divergent political systems, having India, Brazil and South Africa as democratic regimes on the one hand, and the Chinese dictatorship and Russian authoritarianism on the other. This also limits the group's objectives in matters such as democracy and human rights. Much of the potential of the BRICS depends on reaching agreements among them at a global level despite internal differences and international interest.

All BRICS countries have relative military strength; including China, Russia and India have nuclear power. But this element has not been fundamental in its tool in the Contemporary Global Order, since it is not an ideal instrument to achieve its main objectives, and it is the space where the United States maintains greater superiority. But it is an important persuasive element to avoid the unilateral interventions of the world powers in regional problems or of any country in the region.

\section{BRICS Role in the Global Contemporary System}

Acharya (2018) defines the Contemporary Global Order as a multicomplex where the actors are more deeply interconnected and interdependent and power is decentralized in the sense that, despite the fact that asymmetries and hierarchies still exist, there is no global hegemony. The global agenda is pluralized and, especially, the agency capacity of all the actors, including the weak States, is pluralized, which is especially strategic not only for the countries of the Global South but also for the weak States or Middle Powers of the North that although they are not economically and socio-politically weak internally, they may not be satisfied with

Table 5. Material elements of Brazil

Source: World Bank (2019)

\begin{tabular}{ccccccc}
\hline Years & $\begin{array}{c}\text { GDP } \\
\text { (US \$ at con- } \\
\text { stant 2010 } \\
\text { prices) }\end{array}$ & Population & $\begin{array}{c}\text { Foreign direct } \\
\text { investment }\end{array}$ & $\begin{array}{c}\text { Exports of } \\
\text { goods and } \\
\text { services } \\
\text { (\% of GDP) }\end{array}$ & $\begin{array}{c}\text { Imports of } \\
\text { goods and } \\
\text { services } \\
\text { (\% of GDP) }\end{array}$ & $\begin{array}{c}\text { Commercial } \\
\text { Opening }\end{array}$ \\
\hline 2008 & $2.06 \mathrm{E}+12$ & 192979029 & 50716402711 & 13.53400059 & 13.72356887 & $1.33 \mathrm{E}-11$ \\
2009 & $2.05 \mathrm{E}+12$ & 194895996 & 31480932200 & 10.85137114 & 11.2546046 & $1.08 \mathrm{E}-11$ \\
2010 & $2.21 \mathrm{E}+12$ & 196796269 & 88452079264 & 10.73819942 & 11.77920798 & $1.02 \mathrm{E}-11$ \\
2011 & $2.30 \mathrm{E}+12$ & 198686688 & $1.01 \mathrm{E}+11$ & 11.46613801 & 12.23551783 & $2.30 \mathrm{E}+12$ \\
2012 & $2.34 \mathrm{E}+12$ & 200560983 & 86606502981 & 11.70305477 & 13.06225025 & $1.06 \mathrm{E}-11$ \\
2013 & $2.41 \mathrm{E}+12$ & 202408632 & 69686087841 & 11.63018213 & 13.93167816 & $1.06 \mathrm{E}-11$ \\
2014 & $2.42 \mathrm{E}+12$ & 204213133 & 97179590335 & 11.01194282 & 13.673463 & $1.02 \mathrm{E}-11$ \\
2015 & $2.34 \mathrm{E}+12$ & 205962108 & 74718044774 & 12.90019142 & 14.05343452 & $1.15 \mathrm{E}-11$ \\
2016 & $2.26 \mathrm{E}+12$ & 207652865 & 77794463497 & 12.49461885 & 12.07966389 & $1.09 \mathrm{E}-11$ \\
2017 & $2.28 \mathrm{E}+12$ & 209288278 & 70685049298 & 12.56757437 & 11.55218258 & $1.06 \mathrm{E}-11$ \\
\hline
\end{tabular}


the disparity of power and lack of representation in international institutions. He warns that this Multicomplex Global Order is not a post-West one since the United States will maintain an important role and the central elements of the previous institutional order persist, but SouthSouth relations are being built with greater dynamism, and North-South relations are each more interdependent and reciprocal, even points out that the constitution of the new Global Order is independent of the decline of North American power, since for the first time in the history of humanity several countries simultaneously and in different locations emerge and can interact and affect the Order Global as a whole.

Especially important for the Global South is what Acharya (2014) observes of this multicomplex world referring to the greater importance that regionalism and the regional order take, since the emerging powers of the Global South are presented as regional powers and the weakest countries they have greater agency capacity at this scale, conditions are generated so that regional powers with aspirations to project their power globally are legitimated at the local level, which is an incentive to offer public goods and a more constructive relationship in general, additionally the powers with global pretension have greater limits in this scenario of more developed regionalisms.

McFarlane (2006) points out that emerging powers are considered to be those countries where power grows and are able to dispute the hierarchy of the prevailing international system, and may alter results of policies or actions promoted by other states. Langehove, Zwatjes \& Papanagnou (2016) also point out that the categorization of regional power depends on their financial and monetary capacities, military strength, energy security, among others, but especially on the possibilities of influence and provision of public goods for the neighbors.
In this sense India, Brazil and South Africa can be considered emerging powers. Russia is a traditional power if we take into account its immediate past as one of the poles of the bipolar world. And China from a broader historical perspective could also be considered as a traditional power. Russia and China are not properly emerging but return of powers. And all the BRICS countries, including those that are neighbors and share some areas of influence, are additionally regional powers.

In addition to its regional power BRICS countries have the capacity to influence beyond their regional spaces. China and India thanks to their economic, political and cultural resources are of great influence worldwide. Russia, due to its past as a nuclear superpower and its competition with the United States, has maintained international influence and recognition of its projection of power. Brazil thanks to historical, cultural and linguistic links maintains important ties with Africa. South Africa also maintains ties with the Middle East (Kingah \& Quiliconi, 2016).

Noltle (2010) warns that during the North American hegemony the regional subsystems were within the conditioning of the world hierarchy, and that the United States interferes in its dynamics to maintain the balance and status quo that allows it to preserve its interests. While in the contemporary period the emergence of regional powers has allowed to generate coalitions and channel demands of autonomy in front of world powers, and alliances in international forums to resolve or autonomously avoid regional conflicts.

The rise of emerging powers allows other smaller countries to join them to diversify their international relations. This has configured a multipolar or apolar world; since the alliances and the actions of the countries are diffuse and fluid, it does not have the clarity and stability that it had in the bipolar or unipolar world 
Available Online at https://journal.unismuh.ac.id/index.php/otoritas

Otoritas : Jurnal Ilmu Pemerintahan, 9 (2), October 2019, 102

(Gratius, 2008).

The strategy of the BRICS countries at a global and regional level has been preponderantly of coexistence. The strategy of coexistence consists of persuasion and attraction skills to influence the decisions of other countries with more modest capabilities and without threats of conflicts. The basic principles of the coexistence strategy are mutual respect for sovereignty, interference in the internal affairs of other countries only within the framework of multilateral agreements, and the promotion of mutual benefits. Each member of the group will prioritize these principles in their foreign policy depending on the region in which they are located, their neighbors and the global aspirations that they have (Coning, Mandrup \& Odgaard, 2015).

Nye (2011a, 2011b, 2003) states that in contemporary times the power is distributed in the form of threedimensional chess, where there is an upper board corresponding to classical military affairs, an intermediate board referring to the economic and finally the lower board where the transnational affairs unfold. United States in the top board is still the hegemon without any competition in sight, in the economic board increasingly loses more space with the emergence of countries like China, and in the lower board increasingly has less control over terrorists, drug dealers weapons and drugs, hackers among other matter. At the beginning of the 21st century the United States was responsible for almost half of the world's military expenditures, no coalition could counterbalance or be able to establish a balance of military power of the traditional type, in fact since the time of Rome there has been no other nation that prevailed so widely over the others.

Therefore, the main area of action of the BRICS has been on the board of the institutions of international political economy. As previously noted, the BRICS countries and especially China consider that the institutions of the international economic system derived from the Bretton Woods agreements after the Second World War, the International Monetary Fund (IMF) and the World Bank (WB), are

Table 6. Material elements of South Africa

Source: World Bank (2019)

\begin{tabular}{lcccccc}
\hline Years & $\begin{array}{c}\text { GDP } \\
\text { (US \$ at con- } \\
\text { stant 2010 } \\
\text { prices) }\end{array}$ & Population & $\begin{array}{c}\text { Foreign direct } \\
\text { investment }\end{array}$ & $\begin{array}{c}\text { Exports of } \\
\text { goods and } \\
\text { services } \\
\text { (\% of GDP) }\end{array}$ & $\begin{array}{c}\text { Imports of } \\
\text { goods and } \\
\text { services } \\
\text { (\% of GDP) }\end{array}$ & $\begin{array}{c}\text { Commercial } \\
\text { Opening }\end{array}$ \\
\hline 2008 & $3.70 \mathrm{E}+11$ & $50,412,129$ & 9885001293 & 35.62243807 & 37.24295217 & $1.97 \mathrm{E}-10$ \\
2009 & $3.64 \mathrm{E}+11$ & $50,970,818$ & 7624489974 & 27.91188817 & 27.50637343 & $1.52 \mathrm{E}-10$ \\
2010 & $3.75 \mathrm{E}+11$ & 51584663 & 3693271715 & 28.61523693 & 27.37375583 & $1.49 \mathrm{E}-10$ \\
2011 & $3.88 \mathrm{E}+11$ & 52263516 & 4139289123 & 30.46094153 & 29.65169022 & $1.55 \mathrm{E}-10$ \\
2012 & $3.96 \mathrm{E}+11$ & 52998213 & 4626029122 & 29.72387936 & 31.17582008 & $1.54 \mathrm{E}-10$ \\
2013 & $4.06 \mathrm{E}+11$ & 53767396 & 8232518816 & 30.97134112 & 33.2704187 & $1.58 \mathrm{E}-10$ \\
2014 & $4.14 \mathrm{E}+11$ & 54539571 & 5791659020 & 31.46864521 & 32.9658559 & $1.56 \mathrm{E}-10$ \\
2015 & $4.19 \mathrm{E}+11$ & 55291225 & 1521139945 & 30.15604561 & 31.4441028 & $1.47 \mathrm{E}-10$ \\
2016 & $4.21 \mathrm{E}+11$ & 56015473 & 2215307020 & 30.70259741 & 30.08792761 & $1.44 \mathrm{E}-10$ \\
2017 & $4.27 \mathrm{E}+11$ & 56717156 & 1371931600 & 29.77288874 & 28.40673945 & $1.36 \mathrm{E}-10$ \\
\hline
\end{tabular}


restrictive for their interests, are at the service of the United States and its allies, and reflect a dynamic of power that no longer corresponds to the current one, and for that reason they seek to reform them. In the IMF the United States has the greatest weight; it is who has the highest number of votes, which are calculated according to the quotas provided by each country. China especially since 2014 has demanded that these quotas be reformed for the votes since the size of its Gross Domestic Product (GDP) and that of its international reserves has grown, however the reform that was carried out has not left it satisfied.

China in the search for an alternative financial architecture seeks to attract other countries that are dissatisfied with the current rules of the game and offers them incentives such as financing for infrastructure and development, which in many aspects can be obtained more easily than in the Bretton Woods multilateral organizations (Destradi, 2010).

The BRICS and especially China, work in two arenas in parallel, in one seek to reform institutions, noting the importance of their economies in the international system, so they must be taken into account to establish the rules of the game. In the second, they are creating other international institutions that coexist and allow the generation of alternatives to contemporary ones, with an emphasis on the South-South vision. The weighting of the strategies and the critical vision of the institutions of international political economy vary within the group, with China and Russia being the most critical and India the least.

Finally, on the third board, on transnational issues, the BRICS together with the G-20 are two of the main examples of the relative success of multilateralism, while the multilateral capacity of the United States has fallen to its historical lows, especially during the administrations of George W. Bush and Donald Trump. In the
Contemporary Global Order multilateralism is even more necessary; in this the BRICS also advance the United States.

\section{CONCLUSION}

The BRICS do not claim or have the capacity to become hegemons. In military matters, its capabilities are only persuasive and secondary because the United States continues to maintain an unquestionable command in this area and its main objectives require other instruments. In matters of transnational affairs, despite its limitations, it has been one of the clearest examples of the success of multilateralism in the Global South. The objectives and capabilities of the BRICS have been especially notable in terms of international political economy, especially in the financial architecture, where China has its greatest power.

In this matter of international political economy the BRICS have proposed a strategy in two spaces, on the one hand seeking to reform the institutions or rules of the international economic system to have greater participation in the decision making of those institutions, while on the other hand They are creating new alternative institutions and regional blocks in parallel, as well as acting individually with their initiatives and commercial and financial agreements.

The BRICS can promote an alternative to the existing game rules in the international system and promote a more plural world. They have the capacity to reform and build international economic institutions that allow a fairer distribution of material resources. They can curb unilateral global power interventions in regional affairs, framing interventions for humanitarian causes within multilateralism and the Responsibility to Protect. In terms of democracy and human rights, they will not make any contribution since their main actors, such as China and Russia, are examples of disrespect for these values. 
Available Online at https://journal.unismuh.ac.id/index.php/otoritas

Otoritas : Jurnal Ilmu Pemerintahan, 9 (2), October 2019, 104

\section{ACKNOWLEDGEMENT}

The authors thank the Research Group on Development and Democracy Studies (GISEDD) for being a privileged space for analysis and debate.

\section{REFERENCES}

Acharya, A. (2018). Constructing Global Order. Agency and change in world politics. United Kingdom: Cambridge University Press.

Acharya, A. (2014). The end of American World Order. United Kingdom: Polity Press.

Bank, W. (2019). Material Elements of Brics Countries. Retrieved from https://databank.worldbank.org/ BRICS-COUNTRIES

Brenner, R. (2009) La economía de la turbulencia global, Madrid, España: AKAL.

Castro de Neves, J.A. (2013). Brasil as an emerging power in Twenty First Century. V. Nadkami, N. C. Noonan. (Eds), Emerging powers in a comparative perspective.The political and economic rise of the BRIC countries, (pp. 189-208). New York, United State of America: Bloomsbury.

Chang, H.J. (2009). Industrial Policy: Can WeGoBeyondanUnproductiveConfrontation? Seul, Corea del Sur: ABCDE (AnnualWorld Bank ConferenceonDevelopmentEconomics).

Coning C. (2015). BRICS and the coexistence. C. de Coning, T. Mandrup y L. Odgaard (Eds), The BRICS and coexistence. An alternative vision of world order. (pp. 25-48). London and New York: Rotledge.
Coning de, C. T. Mandrup y L. Odgaard. (2015). Coexistence in between world order and national interest. C. de Coning, T. Mandrup y L. Odgaard (Eds), The BRICS and coexistence.An alternative vision of world order, ( pp.171-181). London and New York: Rotledge.

Deciancio, M. (2015). Brazil's Leadership through global channel: autonomy, diversification and acceptance. S. Kingah, y C. Quiliconi (Eds), Global and regional leadership of Brics Countries, (pp. 49-66). New York, United States of America: United Nations University-Springer.

Destradi, S. (2010). Regional powers and their strategies: Empire, hegemony, and leadership. Review of international Studies. 36(4) 903-930.

Fleming Splidboel H. and A. Sergunin, (2015) Russia, BRICS, and Peaceful coexistence. Between Idealism and instrumentalism. C. de Coning, T. Mandrup y L. Odgaard (Eds), The BRICS and coexistence. An alternative vision of world order, (pp. 7599). London and New York: Rotledge.

Fuente Cobo, I. (2011). La India como Gran potencia. A. Argumosa Pila (Ed), Brasil, Rusia, India y China (BRIC): una realidad geopolítica singular, (pp. 57-81) Madrid, España: Centro superior de Estudios de la Defensa Nacional.

Gratius, S. (2008). Las potencias emergentes: ¿Estabilizadoras o desestabilizadoras?, comentario FRIDE, Fundación para las Relaciones Internacionales y el Dialogo Exterior, 4 (4)1-16. 
Available Online at http://journal.unismuh.ac.id/index.php/otoritas

Otoritas : Jurnal Ilmu Pemerintahan, 9 (2), October 2019, 105

Gu, J., Carey, R., Shankland, A., \& Chenoy, A. (2016). Introduction: international development, South-South Cooperation and the rising powers. In The BRICS in International Development (pp. 1-24). Palgrave Macmillan, London.

Gupta, S. y S. Chatterjee. (2015). Indian foreign policy and coexistence. Continuity an change in the post cold war era. C. de Coning, T. Mandrup y L. Odgaard (Eds), The BRICS and coexistence. An alternative vision of world order, (pp.100124). London and New York: Rotledge.

Ikenberry, J. (2008). The Rise of China and the Future of the West. Foreign Affairs, 87 (1). 23 - 37.

Keohane, R. y Nye, J. (2012) Power and Interdependence. New York, United States of America: Pearson.

Kiely, R. (2015) The BRICs, US 'Decline' and global transformation. New York, United States of America: Palgrave- McMillan.

Kingah, S. y C. Quiliconi. (2015). Introduction: The BRICS in Global and Regional Governance, S. Kingah, y C. Quiliconi (Eds), Global and regional leadership of Brics Countries, (pp.1-11). New York: United Nations University, Springer, New York.

Kugler, J., y A. Organski. (1989). The Power Transition, M. Midlarsky (Ed.), Handbook of War Studies (pp. 171194). Ann Arbor: University of Michigan Press.

Langehove, L. M. Zwartjes and Papanagnonu, G. (2015). Conceptualising Regional Leadership: The posi- tioning Theory Angle. S. Kingah, y C. Quiliconi (Eds), Global and regional leadership of Brics Countries, (pp.13-27). New York: United Nations University, Springer.

Luft, G. Korin, A. (2009). Energy Security: In the Eyes of the Beholder. G. Luft, A. Korin (Eds), Energy Security Challenges for the 21 ${ }^{\text {st }}$ Century, (pp. 1-17).Santa Barbara, CA: Praeger Security International.

Luna, L. (2014). La C de los BRICS: el rol de China en la consolidación del grupo. OASIS, (19), 53-66.

MacFarlane, N. (2006) The ' $R$ ' in the BRICs: is Russia an emerging Power? International Affairs, 82(1) 41-57.

Mandrup, T. and Karen S. (2015). South Africa's "diplomacy of ubuntu": an African approach to coexistence? C. de Coning, T. Mandrup y L. Odgaard (Eds), The BRICS and coexistence. An alternative vision of world order, (pp. 149-170). London and New York: Rotledge.

Noltle, D. (2010). How to compare regional powers: analytical concepts and research topics. Review of international Studies. 36(4), 881-901.

Nye, J. (2011a). The Future of Power. Nueva York, PublicAffairs.

Nye, J. (2011b). El futuro del poder estadounidense. Foreign Affairs en español, 11 (1). 97 - 109.

Nye, J. (2003). La paradoja del poder norteamericano, Madrid, España: Taurus.

Odgaard, L. y Zhan D. (2015). China and Coexistence. Beijing's policies on 
Available Online at http://journal.unismuh.ac.id/index.php/otoritas

Otoritas : Jurnal Ilmu Pemerintahan, 9 (2), October 2019, 106

energy, United Nations Security Council. Diplomacy and Sovereignty disputes. C. de Coning, T. Mandrup y L. Odgaard (Eds), The BRICS and coexistence. An alternative vision of world order. (pp. 125148). London and New York: Rotledge.

Stein, A. (1984). A Hegemon's Dilemma, En: International Organization, 38 (2), 355-386.

Stuenkel, 0. (2015) The BRICS and the future of global order, London, United Kingdon: Lexington Books.
UNICEF (2012). Estadísticas del estado de la niñez en Sudáfrica. Retrieved from http://www.unicef.org/ spanish/infobycountry/ southafrica statistics.html

Waltz, K. (1979) Theory of International Politics, New York, McGraw-Hill.

Went, A. (1992) Anarchy is what states make of it: the social construction of power politics. En: International Organization, 46 (2), 391-425. 